\title{
Effect of cadmium-induced oxidative stress on antioxidative enzymes in mitochondria and cytoplasm of CRL-1439 rat liver cells
}

\author{
LEKAN M. LATINWO ${ }^{1}$, VEERA L. BADISA ${ }^{1,2}$, CHRISTOPHER O. IKEDIOBI ${ }^{2}$, \\ CAROLINE O. ODEWUMI ${ }^{1}$, AYUK-TAKEM T. LAMBERT ${ }^{2}$ and RAMESH B. BADISA ${ }^{3}$ \\ Departments of ${ }^{1}$ Biology, ${ }^{2}$ Chemistry, College of Arts and sciences; ${ }^{3}$ College of Pharmacy and \\ Pharmaceutical Sciences, Florida A\&M University, Tallahassee, FL 32307, USA
}

Received March 7, 2006; Accepted May 11, 2006

\begin{abstract}
Cadmium affects human health through occupational and environmental exposure. In this report, we present the response of mitochondrial and cytoplasmic antioxidant enzymes of CRL-1439 cells exposed to different concentrations $(0-150 \mu \mathrm{M})$ of $\mathrm{CdCl}_{2}$ for $24 \mathrm{~h}$ at $37^{\circ} \mathrm{C}$. Exposure of liver cells to $50 \mu \mathrm{M} \mathrm{CdCl}_{2}$ increased mitochondrial catalase and glutathione reductase (GR) activities more than the cytoplasmic enzymes. Although the mitochondrial selenium-dependent glutathione peroxidase (Se-GPx) showed less enzymatic activity than the cytoplasmic enzyme, the mitochondrial selenium-independent glutathione peroxidase (non-Se-GPx) showed a slight increase in activity over its cytoplasmic counterpart compared to untreated controls. With $100 \mu \mathrm{M}$ $\mathrm{CdCl}_{2}$, catalase maintained an increase in specific activity in mitochondria over the cytoplasmic enzyme compared to the controls. The level of GR was higher in the cytoplasm than in the mitochondria. However, the activity of Se-GPx and nonSe-GPx decreased slightly in the mitochondria compared to their cytoplasmic counterparts. Exposure of cells to $150 \mu \mathrm{M}$ $\mathrm{CdCl}_{2}$ decreased all antioxidant enzyme activities compared to the $100 \mu \mathrm{M} \mathrm{CdCl}_{2}$-treated samples due to toxic effect. Each antioxidant enzyme exhibited its own pattern of activation or inhibition upon exposure to different concentrations of cadmium, with more oxidative stress observed in the mitochondria.
\end{abstract}

\section{Introduction}

Cadmium, a heavy toxic metal that is widely used in industry, affects human health through occupational and environmental

Correspondence to: Dr L.M. Latinwo, Department of Biology, College of Arts and sciences, Florida A\&M University, Tallahassee, FL 32307, USA

E-mail: lekan.latinwo@famu.edu

Key words: cadmium, catalase, glutathione reductase, glutathione peroxidase, mitochondria exposure. It is present in soils, sediments, air and water and is listed by the US Environmental Protection Agency as one of 126 priority pollutants (1). Today, the main uses for this metal are for nickel-cadmium battery manufacture, pigments and plastic stabilizers. Anthropogenic sources of cadmium in the environment are from refining, copper and nickel smelting, and fossil fuel combustion. Natural sources of cadmium in the atmosphere are from volcanic activity, forest fires and wind-borne transport of soil particles. Irwin et al (2) reported that anthropogenic sources add 3-10 times more cadmium to the atmosphere than natural sources. Major occupational exposure occurs in non-ferrous smelters, from the production and processing of cadmium, its alloys and compounds, and increasingly in the recycling of electronic waste. Nonoccupational exposure is mainly from cigarette smoke that contains high concentrations of cadmium. For non-smokers who are not occupationally exposed, diet is the main route of exposure to cadmium.

The half-life of cadmium in humans is estimated to be between 15 and 20 years (3). It can cause osteoporosis, nonhypertrophic emphysema, irreversible renal tubular injury, anemia, eosinophilia, anosmia and chronic rhinitis (4). Cadmium has been classified as a category I carcinogen (human carcinogen) by the International Agency for Research on Cancer, (5) and the National Toxicology Program, (6). It can cause cancer in the lung, the prostrate, the pancreas and the kidney.

The basic mechanisms involved in cadmium carcinogenesis are gene regulation of proto-oncogenes (7), oxidative stress (8-12), disruption of cadherins, inhibition of DNA repair and interference with apoptosis (13). Recently, we studied the response of antioxidant enzymes and redox metabolites in CRL-1439 normal rat liver cells due to cadmium-induced oxidative stress (12). Enzymes involved in the detoxification of oxygen radicals are present in two organelles, peroxisomes and mitochondria. It is well-documented that oxygen reduction occurs in the mitochondria, generating reactive oxygen species (ROS) such as superoxide $\left(\mathrm{O}_{2}^{-}\right)$and hydrogen peroxide $\left(\mathrm{H}_{2} \mathrm{O}_{2}\right)$ which accumulate as a result of either autooxidation of ubisemiquinone of the cytochrome bc1 complex or by spontaneous and/or enzymatic dismutation of $\mathrm{O}_{2}^{-}(14,15)$. The main scavengers of $\mathrm{O}_{2}^{-}$and $\mathrm{H}_{2} \mathrm{O}_{2}$ in the mitochondria are superoxide 
dismutase (Mn-SOD), catalase, glutathione peroxidase, and peroxiredoxins (16-20). Since these enzymes are present both in the cytoplasm and in the mitochondria of the cells, the response of antioxidant enzymes to different concentrations of cadmium was investigated in the present study with a view to compare these enzyme activities.

\section{Materials and methods}

Maintenance of cell line. Rat normal liver epithelial cell line was purchased from the American Type Culture Collection (ATCC) catalog no. CRL-1439 at the passage number 17 stage. The supplied frozen cells were cultured according to ATCC instructions. Cells were grown in $\mathrm{F} 12 \mathrm{~K}$ medium containing $2 \mathrm{mM}$ L-glutamine, supplemented with $10 \%$ fetal bovine serum, 100 units $/ \mathrm{ml}$ penicillin, and $100 \mu \mathrm{g} / \mathrm{ml}$ streptomycin in T-75 $\mathrm{mm}^{2}$ flasks (Greener Labortecknik) in a humidified chamber with $5 \% \mathrm{CO}_{2}$ in air at $37^{\circ} \mathrm{C}$ in an incubator (Nuiare Co).

Preparation of cytoplasmic and mitochondrial enzyme extracts. Approximately $1 \times 10^{7}$ cells grown in $\mathrm{T}-75 \mathrm{~mm}^{2}$ flasks were used for preparing cytoplasmic and mitochondrial enzyme extracts. The cells were treated with $0,50,100$ and $150 \mu \mathrm{M}$ $\mathrm{CdCl}_{2}$ and incubated for $24 \mathrm{~h}$ at $37^{\circ} \mathrm{C}$ in a $5 \% \mathrm{CO}_{2}$ incubator. At the end of incubation, the cells were trypsinized and pelleted by centrifuging at 3,500 rpm for $10 \mathrm{~min}$. The cell pellets from two flasks were pooled and washed once with cold PBS. Mitochondria were isolated by the method of Guerra (21). In brief, each cell pellet was suspended in $1 \mathrm{ml}$ of ice-cold isolation solution $(0.33 \mathrm{M}$ sucrose, $0.25 \mathrm{mM}$ $\mathrm{Na}_{2}$ EDTA, $15 \mathrm{mM}$ Tris- $\mathrm{HCl}$ ( $\mathrm{pH}$ 7.4) and homogenized in a vial for $1 \mathrm{~min}$ at intervals of $15 \mathrm{sec}$, using a Polytron homogenizer. The homogenate was transferred to an Eppendorf tube and centrifuged at $3,000 \mathrm{rpm}$ for $10 \mathrm{~min}$ at $4^{\circ} \mathrm{C}$ to remove the lysed cell membrane debris. The supernatant was transferred into different tubes and again centrifuged at $10,000 \mathrm{rpm}$ for $10 \mathrm{~min}$. The obtained supernatant was the source of cytoplasmic fraction utilized in enzyme assay studies. The pellet was suspended in $500 \mu 1$ of $0.33 \mathrm{M}$ sucrose and centrifuged at $10,000 \mathrm{rpm}$ for $10 \mathrm{~min}$. The pellet containing the mitochondria was suspended in $500 \mu 1$ of $0.33 \mathrm{M}$ sucrose. The remaining supernatant was pooled with the cytoplasmic fraction. Both fractions were stored at $4^{\circ} \mathrm{C}$ till further use.

\section{Enzyme assays}

Catalase. Catalase activity was assayed according to the method of Aebi (22). The assay volume $(900 \mu \mathrm{l})$ contained $50 \mu 1$ cell extract and $550 \mu 1$ of $50 \mathrm{mM}$ phosphate buffer $\mathrm{pH}$ 7.0. The reaction at $37^{\circ} \mathrm{C}$ was started by the addition of $300 \mu \mathrm{l}$ of $30 \mathrm{mM} \mathrm{H}_{2} \mathrm{O}_{2}$. The decrease in absorbance at $240 \mathrm{~nm}$ was monitored for $60 \mathrm{sec}$ in a Beckman DU 7500 spectrophotometer. The enzyme activity was calculated using the extinction coefficient of $0.003941 \mathrm{mmol}^{-1} \mathrm{~mm}^{-1}$ and the unit of enzyme activity was expressed as mmoles $\mathrm{H}_{2} \mathrm{O}_{2}$ decomposed per minute.

Glutathione reductase. Glutathione reductase activity was assayed according to Smith et al (23). This assay is based on the following reactions:

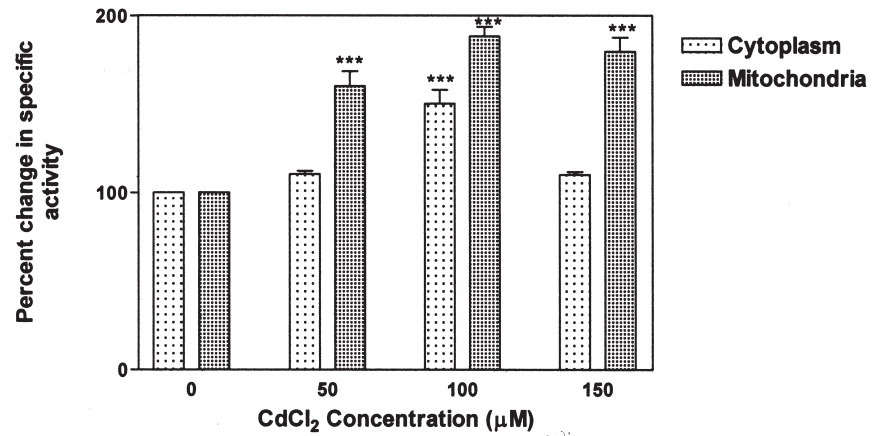

Figure 1. Effect of $\mathrm{CdCl}_{2}$ on catalase in cytoplasm and mitochondria of rat normal liver cells. Approximately $10 \times 10^{6}$ cells were treated with 0, 50, 100 and $150 \mu \mathrm{M} \mathrm{CdCl}_{2}$ and incubated for $24 \mathrm{~h}$ at $37^{\circ} \mathrm{C}$ in a $5 \% \mathrm{CO}_{2}$ incubator. The cells were trypsinized and pelleted by centrifuging at 3,500 rpm for $10 \mathrm{~min}$. The mitochondrial and cytoplasmic extracts were prepared according to the method of Guerra (21). Fifty microliters of the extracts was used in enzyme assays. Data are expressed as mean $\pm \mathrm{SD}, \mathrm{n}=3$. $^{* * *} \mathrm{p}<0.01$ was considered highly significant.

$$
\begin{aligned}
& \mathrm{NADPH}+\mathrm{H}^{+}+\mathrm{GSSG}_{\text {reductase }}^{\stackrel{\text { glutathione }}{\rightarrow}} \mathrm{NADP}^{+}+2 \mathrm{GSH} \\
& \mathrm{GSH}+\mathrm{DTNB} \rightarrow \mathrm{GSTNB}+\mathrm{TNB}
\end{aligned}
$$

The change in absorbance at $412 \mathrm{~nm}$ due to the formation of TNB was measured. The specificity of this assay allows quantification of glutathione reductase without purification. The assay volume $(2 \mathrm{ml})$ contained $1 \mathrm{ml}$ of $0.2 \mathrm{M}$ potassium phosphate with $1 \mathrm{mM}$ EDTA buffer $\mathrm{pH} 7.5,500 \mu \mathrm{l}$ of $3 \mathrm{mM}$ DTNB [5'5-dithiobis (2-nitrobenzoic acid)] in $0.01 \mathrm{M}$ phosphate buffer $\mathrm{pH} 7.0,250 \mu 1$ distilled water, $100 \mu 1$ of $2 \mathrm{mM}$ NADPH in water, $50 \mu 1$ cell extract and $100 \mu 1$ of $20 \mathrm{mM}$ oxidized glutathione. The increase in absorbance at $412 \mathrm{~nm}$ was monitored for $3 \mathrm{~min}$ in a Beckman DU 7500 spectrophotometer at $24^{\circ} \mathrm{C}$. The enzyme activity was calculated using the extinction coefficient of TNB to be $\left(\mathrm{E}_{412}=13.61\right.$ $\left.\mathrm{mmol}^{-1} \mathrm{~cm}^{-1}\right)$. One unit of enzyme activity is defined as the amount of enzyme that catalyzes the oxidation of $1 \mu$ mole NADPH per minute.

Glutathione peroxidase ( $G P x)$. Glutathione peroxidase activity was assayed according to the method of Yang et al (24). Briefly, the reaction mixture $(0.5 \mathrm{ml})$ contained $3.2 \mathrm{mM}$ GSH, 0.32 mM NADPH, 1 unit glutathione reductase (GR), $1 \mathrm{mM}$ sodium azide and $0.82 \mathrm{mM}$ EDTA in $0.16 \mathrm{M}$ Tris- $\mathrm{HCl}$, $\mathrm{pH}$ 7.0. When $\mathrm{H}_{2} \mathrm{O}_{2}$ was used as a substrate, $1 \mathrm{mM}$ sodium azide was added to the reaction mixture to inhibit endogenous catalase activity. The reaction mixture was pre-incubated with $50 \mu \mathrm{l}$ of sample at $37^{\circ} \mathrm{C}$ for $5 \mathrm{~min}$. The reaction was started by addition of cumene hydroperoxide and $\mathrm{H}_{2} \mathrm{O}_{2}$ or $\mathrm{H}_{2} \mathrm{O}_{2}$ alone at a final concentration of $100 \mu \mathrm{M}$ in the reaction mixture. The rate of NADPH consumption was monitored at $340 \mathrm{~nm}$ for $3 \mathrm{~min}$. One unit of GPx activity was defined as the amount of enzyme that catalyzes the oxidation of $1 \mu \mathrm{mol}$ of NADPH/min in the coupled assay. Se-dependent GPx was calculated from the change in absorbance using only $\mathrm{H}_{2} \mathrm{O}_{2}$ as substrate. Se-independent GPx was calculated by subtracting the change in absorbance at $340 \mathrm{~nm} / \mathrm{min}$ with $\mathrm{H}_{2} \mathrm{O}_{2}$ from the absorbance at $340 \mathrm{~nm} / \mathrm{min}$ with cumene hydroperoxide and $\mathrm{H}_{2} \mathrm{O}_{2}$ substrates in the reaction. 


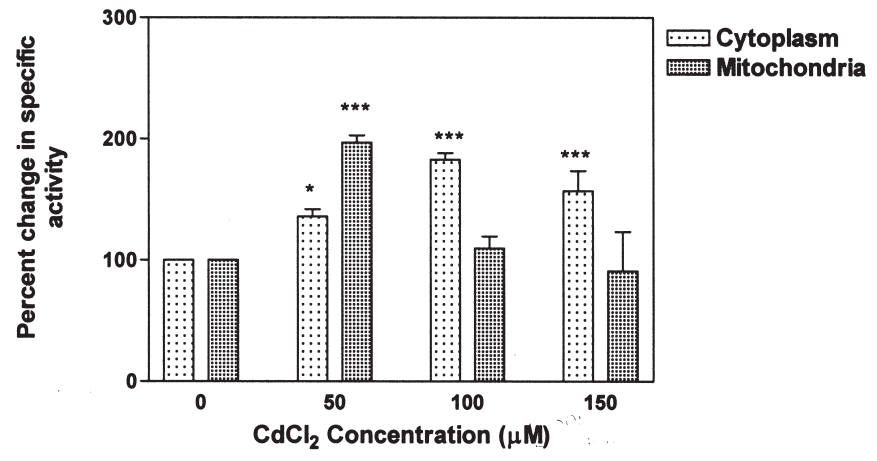

Figure 2. Effect of $\mathrm{CdCl}_{2}$ on glutathione reductase in cytoplasm and mitochondria of rat normal liver cells. Approximately $10 \times 10^{6}$ cells were treated with $0,50,100$ and $150 \mu \mathrm{M} \mathrm{CdCl}_{2}$ and incubated for $24 \mathrm{~h}$ at $37^{\circ} \mathrm{C}$ in a $5 \% \mathrm{CO}_{2}$ incubator. The cells were trypsinized and pelleted by centrifuging at 3,500 rpm for $10 \mathrm{~min}$. The mitochondrial and cytoplasmic extracts were prepared according to the method of Guerra (21). Fifty microliters of the extracts were used in the enzyme assays. Data are expressed as mean $\pm \mathrm{SD}, \mathrm{n}=3$. ${ }^{*} \mathrm{p}<0.05$ and ${ }^{* * *} \mathrm{p}<0.01$ were considered significant and highly significant respectively.

Protein estimation. The protein contents of the enzyme extracts were measured using a unique method that combines the reduction of $\mathrm{Cu}^{+1}$ by proteins in an alkaline medium (Biuret reaction) with the highly-sensitive and selective colorimetric detection of cuprous cation $\left(\mathrm{Cu}^{+1}\right)$ using reagent containing bicinchonic acid $(25,26)$. Protein contents were used to calculate specific activities of the enzymes and subsequently to estimate percent increase/decrease in enzyme activities at different concentrations of $\mathrm{CdCl}_{2}$.

Statistical analysis. The experimental results were presented as mean $\pm \mathrm{SD}(\mathrm{n}=3)$. The data were analyzed for significance by one-way ANOVA, and then compared by Dunnett's multiple comparison test, using GraphPad Prism Software, version 3.00 (San Diego, CA). The test values $\mathrm{p}<0.05$ and $\mathrm{p}<0.01$ were considered significant and highly significant respectively in comparison to the respective untreated control.

\section{Results}

Comparison of the catalase activity in the mitochondria and cytoplasm due to cadmium-induced oxidative stress. The effects of cadmium-induced ROS production on mitochondrial (M-catalase) and cytoplasmic (C-catalase) catalase activities were investigated. For this purpose, normal rat liver epithelial cells were treated with cadmium at 50,100 and $150 \mu \mathrm{M}$ for $24 \mathrm{~h}$. The data are presented in Fig. 1. The results clearly indicate that cadmium at 50,100 and $150 \mu \mathrm{M}$ increased the M-catalase activity by $60.3 \%, 88.0 \%$ and $80 \%$, respectively, in comparison to untreated control. In the case of C-catalase, cadmium treatments (50 and $100 \mu \mathrm{M})$ caused increased activity of $10.4 \%$ and $50.5 \%$, respectively, when compared to the untreated control. Further increase in cadmium concentration $(150 \mu \mathrm{M})$ decreased $(40 \%)$ the C-catalase activity to the level of control. Comparison of M-catalase and C-catalase revealed that the M-catalase showed higher enzyme activity (30-50\%) than the $\mathrm{C}$-catalase. The significance of increased activity may be correlated to increased ROS production in mitochondria due to cadmium treatment.

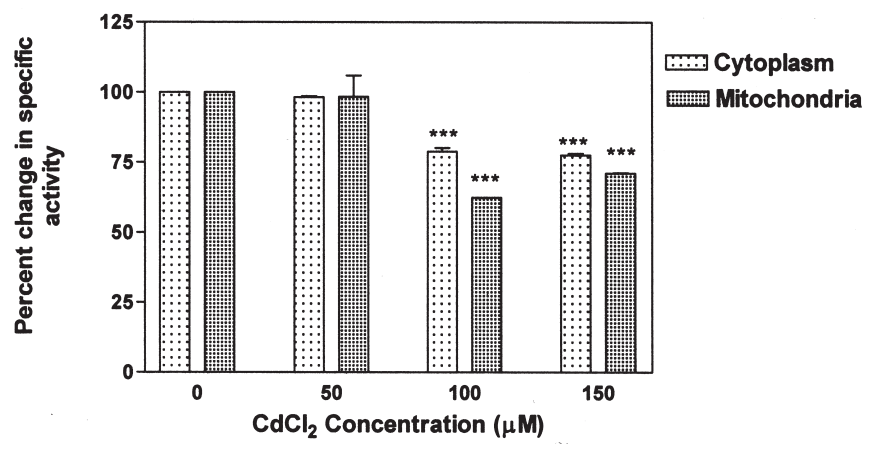

Figure 3. Effect of $\mathrm{CdCl}_{2}$ on selenium-dependent glutathione peroxidase activity in the cytoplasm and in the mitochondria of rat normal liver cells. Approximately $10 \times 10^{6}$ cells were treated with $0,50,100$ and $150 \mu \mathrm{M} \mathrm{CdCl}_{2}$ and incubated for $24 \mathrm{~h}$ at $37^{\circ} \mathrm{C}$ in a $5 \% \mathrm{CO}_{2}$ incubator. The cells were trypsinized and pelleted by centrifuging at $3,500 \mathrm{rpm}$ for $10 \mathrm{~min}$. The mitochondrial and cytoplasmic extracts were prepared according to the method of Guerra (21). Fifty microliters of the extracts were used in enzyme assays. Data are expressed as mean $\pm \mathrm{SD}, \mathrm{n}=3$. ${ }^{* * *} \mathrm{p}<0.01$ was considered highly significant.

Comparison of the glutathione reductase (GR) activity in the mitochondria and cytoplasm due to cadmium-induced oxidative stress. To examine the effect of oxidation stress on the GR enzyme, which was present in the cytoplasm (C-GR) and mitochondria (M-GR), rat liver cells were exposed to various concentrations of cadmium $(50,100$ and $150 \mu \mathrm{M})$ for $24 \mathrm{~h}$ at $37^{\circ} \mathrm{C}$, and the activities in the cytoplasm and mitochondria were determined. The data are shown in Fig. 2. Exposure to $50 \mu \mathrm{M}$ $\mathrm{CdCl}_{2}$ increased the GR activity by $35.8 \%$ and $96.8 \%$ in the cytoplasm and the mitochondria respectively, when compared to the untreated control. However, further increase in cadmium concentrations (100 and $150 \mu \mathrm{M})$ caused a drastic decrease in the M-GR activity ( $90 \%)$ in comparison to its activity at $50 \mu \mathrm{M}$. This level of activity is about the same as that of untreated control. In contrast, the C-GR activity was found to be the highest at $100 \mu \mathrm{M}$ cadmium treatment, whereas only a slight decrease (16\%) in C-GR activity was observed in cells treated with $150 \mu \mathrm{M} \mathrm{CdCl}_{2}$. The high initial increase, followed by sudden decrease ( $\sim 90 \%)$ in M-GR activity may indicate that this enzyme was denatured by high ROS production.

Comparison of the selenium-dependent glutathione peroxidase (Se-GPx) activity in the mitochondria and cytoplasm due to cadmium-induced oxidative stress. The Se-GPx activity in the mitochondria (M-Se-GPx) and cytoplasm (C-Se-GPx) of the liver cells exposed to various concentrations of cadmium (50, 100 and $150 \mu \mathrm{M}$ ) for $24 \mathrm{~h}$ at $37^{\circ} \mathrm{C}$ are shown in Fig. 3. The Se-GPx activity in the cytoplasm and in the mitochondria at $50 \mu \mathrm{M}$ cadmium treatment remained the same as control. However, at $100 \mu \mathrm{M} \mathrm{CdCl}_{2}$ treatment, the activity decreased in the cytoplasm and mitochondria. Further increase in cadmium concentration $(150 \mu \mathrm{M})$ did not decrease the enzyme activity significantly in the cytoplasm, while a small but insignificant increase $(8.6 \%)$ in the activity was noticed in the mitochondrial enzyme when compared to $100 \mu \mathrm{M} \mathrm{CdCl}_{2}$ exposed cells.

Comparison of the selenium-independent glutathione peroxidase (non-Se-GPx) activity in the mitochondria and 


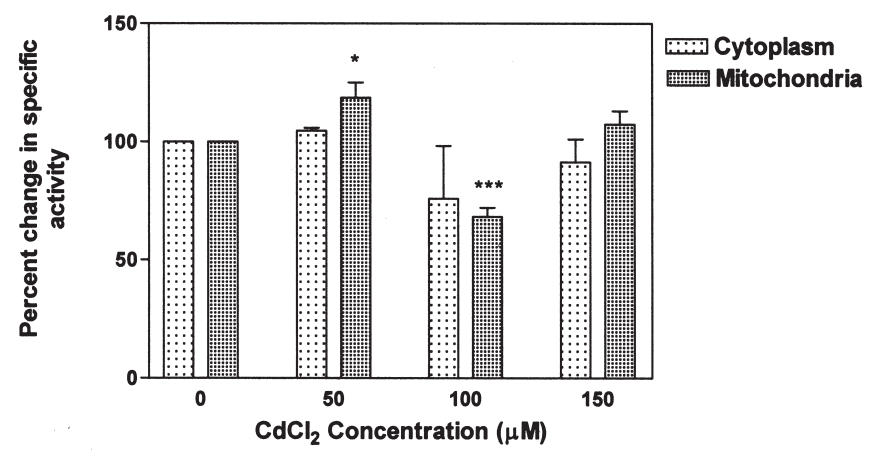

Figure 4. Effect of $\mathrm{CdCl}_{2}$ on selenium-independent glutathione peroxidase activity in the cytoplasm and in the mitochondria of rat normal liver cells. Approximately $10 \times 10^{6}$ cells were treated with $0,50,100$ and $150 \mu \mathrm{M} \mathrm{CdCl}_{2}$ and incubated for $24 \mathrm{~h}$ at $37^{\circ} \mathrm{C}$ in a $5 \% \mathrm{CO}_{2}$ incubator. The cells were trypsinized and pelleted by centrifuging at $3,500 \mathrm{rpm}$ for $10 \mathrm{~min}$. The mitochondrial and cytoplasmic extracts were prepared according to the method of Guerra (21). Fifty microliters of the extracts were used in enzyme assays. Data are expressed as mean $\pm \mathrm{SD}, \mathrm{n}=3 .{ }^{*} \mathrm{p}<0.05$ and ${ }^{* * *} \mathrm{p}<0.01$ were considered significant and highly significant respectively.

cytoplasm due to cadmium-induced oxidative stress. The non-Se-GPx activity in the cytoplasm (C-non-Se-GPx) and mitochondria (M-non-se-GPx) of the liver cells treated with various concentrations of cadmium $(50,100$ and $150 \mu \mathrm{M})$ for $24 \mathrm{~h}$ at $37^{\circ} \mathrm{C}$ are shown in Fig. 4. Exposure of liver cells to $50 \mu \mathrm{M} \mathrm{CdCl}_{2}$ reduced the non-Se-GPx activity to the same level observed in the untreated controls, while an increase of $18.7 \%$ was detected in the mitochondria when compared to the untreated control. Interestingly, treatment with $100 \mu \mathrm{M}$ $\mathrm{CdCl}_{2}$ caused a decrease in enzymatic activity of $24.2 \%$ in the cytoplasm and $31.8 \%$ in the mitochondria. But at $150 \mu \mathrm{M}$ $\mathrm{CdCl}_{2}$, enzymatic activity increased again in both the cytoplasm and mitochondria when compared to the untreated controls.

\section{Discussion}

It is well documented that reactive oxygen species (ROS) play contrasting roles, beneficial and harmful, in living organisms (27). ROS can be generated by both exogenous and endogenous sources. Cadmium is one of the exogenous sources shown to indirectly produce ROS in various cell lines (28-30). The production and accumulation of ROS inhibit the electron transfer chain in mitochondria (31). In general, the accumulated ROS consists of various amounts of hydrogen peroxide, hydroxyl ions, singlet oxygen, superoxide anions, lipid hydroperoxides, phospholipid hydroperoxides etc.

Excessive production of ROS disturbs the balance between the ROS and antioxidant agents (enzymes and antioxidant substances) in the cells. Hydrogen peroxide is the common substrate for catalase and GPx enzymes in the cells. While catalase decomposes $\mathrm{H}_{2} \mathrm{O}_{2}$ into water and oxygen, GPx oxidizes GSH to GSSG by utilizing $\mathrm{H}_{2} \mathrm{O}_{2}$. Another enzyme that is required for the antioxidant defense mechanism is glutathione reductase (GR). It reduces GSSG into GSH. Both GPx and GR work in tandem in the cells in order to maintain the GSH/GSSG ratio at a steady state level. When the cells are under oxidative stress, catalase, GR and GPx respond by altering their activities.
Since the isolation procedure of mitochondria yields $95 \%$ pure mitochondria with only $5 \%$ contamination of peroxisomes (21), the high catalase activity in the mitochondrial fraction indicates the presence of catalase in rat mitochondria in the current study. The presence of catalase in rat liver mitochondria (32) and rat heart mitochondria (14) were reported previously. Since catalase decomposes hydrogen peroxide specifically, the dose-dependent increase in M-catalase activity in this study initiated by increasing doses of cadmium (50 and $100 \mu \mathrm{M}$ ) suggests that hydrogen peroxide is produced in increasing amounts with increasing concentrations of cadmium. The steep increase of M-GR activity at $50 \mu \mathrm{M}$ cadmium indicates accumulation of more GSH in the cells. The high levels of GSH help protect the cells against oxidative stress by quenching different types of radicals of the ROS (33).

Interestingly, the M-Se-GPx activity at $50 \mu \mathrm{M}$ cadmium remained the same as the untreated control. Since GPx competes with catalase for hydrogen peroxide under normal conditions in the cells, the unchanged M-Se-GPx activity at $50 \mu \mathrm{M}$ cadmium in comparison to untreated control indicates that it competed with catalase for hydrogen peroxide at $50 \mu \mathrm{M}$ cadmium treatment. However, treatment with 100 and $150 \mu \mathrm{M}$ cadmium decreased the enzymatic activities of M-GR and M-Se-GPx significantly. At this point, the GSH levels were the same as that of the control, while the GSSG levels were significantly lower than the control. The lower levels of GSSG in comparison to untreated control may also indicate that treatment with 100 and $150 \mu \mathrm{M} \mathrm{CdCl}_{2}$ reduced the ability of M-Se-GPx to compete with catalase for hydrogen peroxide. Since GSH/GSSG ratio is taken as a good measure of the oxidative stress in cells (34), the high levels of GSH compared to the observed levels of GSSG at such cadmium treatments indicate that the cells were not extremely stressed due to treatment with cadmium.

Overall, it appears that when hydrogen peroxide levels in ROS are low, catalase, GR and Se-GPx work in tandem in the cells without disturbing the GSH/GSSG ratio to counteract hydrogen peroxide and various radicals of the ROS. On the other hand, when the production of hydrogen peroxide is high due to high oxidative stress, the situation alters the above ratio and results in increased catalase activity and decreased GR and Se-GPx activities. The altered enzyme activities ensure the efficient removal of ROS in order to maintain the integrity of cell membranes, proteins, DNA etc.

When normal rat liver cells were treated with varying concentrations of cadmium, the mitochondrial enzymes were more effective in reducing various ROS than their cytoplasmic counterparts. This observation may not be surprising in view of the fact that most oxido-reduction reactions take place in the mitochondria, leading to the formation of several ROS (35). As less ROS are produced in the cytoplasm, the activities of antioxidant enzymes in the cytoplasm were not as high as the mitochondrial enzymes with cadmium treatments. Nevertheless, the cytoplasmic enzymes also exhibited similar patterns of activities with cadmium treatments and are thus not discussed separately.

In conclusion, more oxidative stress was observed in the mitochondria than in the cytoplasm. Each antioxidant enzyme shows its own pattern of activation or inhibition upon exposure of cells to different concentrations of cadmium. 


\section{Acknowledgments}

This work was supported by a grant from the National Institute of Health, the National Institute of General Medical Sciences and Minority Biomedical Research Support Program Grant \# S06 GM 08111.

\section{References}

1. Waisberg M, Joseph P, Hale B and Beyersmann D: Review on molecular and cellular mechanisms of cadmium carcinogenesis. Toxicol 192: 95-117, 2003.

2. Irwin RJ, Van Mouwerik M, Stevend L, Seese MD and Basham W: Environmental contaminants encyclopedia. National Park Service, Water Resources Division, Fort Collins, Colorado. Distributed within the federal government as electronic document, retrieved 25 February 2003, form http://www.nature.nps.gov/ toxic/cadmium.pdf.

3. Jin T, Lu J and Nordberg M: Toxicokinetics and biochemistry of cadmium with special emphasis on the role of metallothionein. Neurotoxicol 19: 529-535, 1998.

4. Jarup L and Alfven T: Low level cadmium exposure, renal and bone effects-the OSCAR study. Biometals 17: 505-509, 2004.

5. International agency for research on cancer (IARC): Beryllium, cadmium, mercury and exposures in the glass manufacturing industry. In: International Agency for Research on Cancer Monographs on the Evaluation of Carcinogenic Risks to Humans, vol. 58. IARC Scientific Publications, Lyon, pp119-237, 1993.

6. National toxicology Program: Ninth report on carcinogens. National Toxicology Program, Research Triangle Park, NC, USA, 2000.

7. Hanahan D and Weinberg RA: The hallmarks of cancer. Cell 100: 57-70, 2000 .

8. Thevenod F and Friedmann JM: Cadmium-mediated oxidative stress in kidney proximal tubule cells induces degradation of $\mathrm{Na}+/ \mathrm{K}+$ ATPase through proteasomal and endo-/lysosomal proteolytic pathways. FASEB J 13: 1751-1761, 1999.

9. Piqueras A, Olmos E, Martinez-Solano JR and Hellin E: Cdinduced oxidative burst in tobacco BY2 cells: time course, subcellular location and antioxidant response. Free Radic Res (suppl): S33-S38, 1999.

10. Stohs SJ, Bagchi D, Hassoun E and Bagchi M: Oxidative mechanisms in the toxicity of chromium and cadmium ions. J Environ Pathol Toxicol Oncol 20: 77-88, 2001.

11. Watjen W and Beyermann D: Cadmium-induced apoptosis in C6 glioma cells: influence of oxidative stress. Biometals 17: 65-78, 2004.

12. Ikediobi CO, Badisa VL, Lambert TAT, Latinwo LM and West J: Response of antioxidant enzymes and redox metabolites to cadmium-induced oxidative stress in CRL-1439 normal rat liver cells. Int J Mol Med 14: 87-92, 2004.

13. Shih CM, Ko WC, Wu JS, Wei YH, Wang LF, Chang EE, Lo TY, Cheng $\mathrm{HH}$ and Chen CT: Mediating of caspase-independent apoptosis by cadmium through the mitochondria-ROS pathway in MRC-5 fibroblasts. J Cell Biochem 91: 384-397, 2004.

14. Radi R, Turrens JF, Chang LY, Bush KM, Crapo JD and Freeman BA: Detection of catalase in Rat heart mitochondria. J Biol Chem 266: 22028-22034, 1991.

15. Scandalios JG: The rise of ROS. Trends Biochem Sci 27: 483-486, 2002.

16. Natvig DO, Sylvester K, Dvorachek WH and Baldwin JL: Superoxide dismutases and catalases. In: The Mycota III. Biochemistry and Molecular Biology. Brambl R and Marzulf GA (eds). Springer-Verlag, Berlin, Heidelberg, pp191-209, 1996.
17. Jamieson DJ: Oxidative stress response of the Yeast saccharomyces cerevisiae. Yeast 14: 1511-1527, 1998.

18. Perajas JR, Mianda-Vizuete A, Javanmardy N, Gustafsson JA and Spyrou G: Mitochondria of Saccharomyces cerevisiae contain one-conserved cysteine type peroxiredoxin with thioredoxin peroxidase activity. J Biol Chem 275: 16296-16301, 2000.

19. Sturtz LA, Diekert K, Jensen LT, Lill R and Culotta VC: A fraction of yeast $\mathrm{C}, \mathrm{Zn}$-superoxide dismutase and its metallochaperone, CCC, localize to the intermembrane space of mitochondria. J Biol Chem 276: 38084-38089, 2001.

20. Del LA, Sandalio LM, Altomare DA and Zilinskas BA: Mitochondrial and peroxisomal manganese superoxide dismutase: differential expression during leaf senescence. J Exp Bot 54: 923-933, 2003.

21. Guerra FC: Techniques for mitochondria: Techniques for rat liver mitochondria. Methods Enzymol 31: 299-303, 1974.

22. Aebi H: Catalase in vitro. Methods Enzymol 105: 121-126, 1984.

23. Smith IK, Vierheller TL and Thorne CA: Assay of glutathione reductase in crude tissue homogenates using 5, 5'- dithiobis(2nitrobenzoic acid). Anal Biochem 175: 408-413, 1988.

24. Yang Y, Cheng JZ, Singhaal SS, Saini M, Pandya U, Awasthi S and Awaathi YC: Role of glutathione S-transferases in protection against lipid peroxidation: over expression of hGSTA2-2 in K562 cells protects against hydrogen peroxide induced apoptosis and inhibits JNK and caspase 3 activation. J Biol Chem 276: 19220-19230, 2001

25. Smith PK, Krohn RI, Hermanson GT, Mallia AK, Gartner FH, Provenzano MD, Fujimoto EK, Goeke NM, Olson BJ and Klenk DC: Measurement of protein using bicinchoninic acid. Anal Biochem 150: 76-85, 1985.

26. Brown R, Jarvis $\mathrm{K}$ and Hyland $\mathrm{K}$ : Protein measurement using bicinchoninic acid: elimination of interfering substances. Anal Biochem 180: 136-139, 1989.

27. Valko M, Izakovic M, Mazur M, Rhodes CJ and Telser J: Role of oxygen radicals in DNA damage and cancer incidence. Mol Cell Biochem 266: 37-56, 2004.

28. Price DK and Joshi JG: Ferritin. Binding of beryllium and other divalent metal ions. J Biol Chem 258: 10873-10880, 1983.

29. Szuster-Ciesielska A, Stachura A, Slotwinska M, Kaminska T, Sniezko R, Paduch R, Abramczyk D, Filar J and KandeferSzerszen M: The inhibitory effect of zinc on cadmium-induced cell apoptosis and reactive oxygen species (ROS) production in cell cultures. Toxicol 145: 159-171, 2000.

30. Watanabe M, Henmi K, Ogawa K and Suzuki T: Cadmiumdependent generation of reactive oxygen species and mitochondrial DNA breaks in photosynthetic and non-photosynthetic strains of Euglena gracilis. Comp Biochem Physiol C Toxicol Pharmacol 134: 227-234, 2003.

31. Wang Y, Fang J, Leonard SS and Rao KM: Cadmium inhibits the electron transfer chain and induces reactive oxygen species. Free Radic Biol Med 36: 71434-71443, 2004.

32. Radhakrishnan TM and Sarma PS: Studies on the intracellular localization and incorporation of $59 \mathrm{Fe}$ into catalase in rat liver. Biochem J 93: 440-447, 1964.

33. Masella R, Di Benedetto R, Vari R, Filesi C and Giovannini C: Novel mechanism of natural antioxidant compounds in biological systems: involvement of glutathione and glutathione-related enzymes. J Nutr Biochem 16: 577-586, 2005.

34. Hwang C, Sinskey AJ and Lodish HF: Oxidized redox state of glutathione in the endoplasmic-reticulum. Science 57: 1496-1502, 1992.

35. Inoue M, Sato EF, Nishikawa M, Park AM, Kira Y, Imada I and Utsumi K: Mitochondrial generation of reactive oxygen species and its role in aerobic life. Curr Med Chem 10: 2495-2505, 2003 . 